\title{
Primary Metabolism and Plant Defense-Fuel for the Fire
}

\author{
Melvin D. Bolton \\ United States Department of Agriculture-Agricultural Research Service, Northern Crops Science Laboratory, Fargo, ND, \\ U.S.A.
}

Submitted 6 November 2008. Accepted 9 January 2009.

Plants have the ability to recognize and respond to a multitude of microorganisms. Recognition of pathogens results in a massive reprogramming of the plant cell to activate and deploy defense responses to halt pathogen growth. Such responses are associated with increased demands for energy, reducing equivalents, and carbon skeletons that are provided by primary metabolic pathways. Although pathogen recognition and downstream resistance responses have been the focus of major study, an intriguing and comparatively understudied phenomenon is how plants are able to recruit energy for the defense response. To that end, this review will summarize current research on energy-producing primary metabolism pathways and their role in fueling the resistance response.

Plants persist in environments that abound with pathogens. Because plants do not have an adaptive immune system such as those found in animal systems, they rely on innate immunity to recognize and respond to potential pathogens (Chisholm et al. 2006; Jones and Dangl 2006). Innate immunity is generally divided into two components that activate cellular defense response pathways to halt or slow pathogen growth. The first line of the plant innate immune response is triggered upon detection of microbe-associated molecular patterns (MAMPs, also known as pathogen-associated molecular patterns)—slowly evolving molecular structures unique to microbes that play an essential role in microbial lifestyle (Ausubel 2005; Gohre and Robatzek 2008; He et al. 2007). Recognition of MAMPs such as bacterial flagellin (Gómez-Gómez and Boller 2000) or fungal chitin (Kaku et al. 2006; Miya et al. 2007) can trigger defense responses that facilitate plant immunity. However, successful pathogens evolved the means to suppress MAMP-triggered immunity through the action of effector proteins that function to modulate plant innate immunity to ultimately enable a successful infection (Bolton et al. 2008c; O'Connell and Panstruga 2006; van Esse et al. 2008). In turn, to combat the effects of pathogen effectors, plants evolved the ability to recognize effectors either directly or indirectly through resistance $(\mathrm{R})$ proteins that activate effector-triggered immunity (Bent and Mackey 2007; Chisholm et al. 2006; de Wit 2007; Jones and Dangl 2006).

Corresponding author: M. D. Bolton; E-mail: Melvin.Bolton@ars.usda.gov

* The $e$-Xtra logo stands for "electronic extra" and indicates that Figure 2 appears in color online.

This article is in the public domain and not copyrightable. It may be freely reprinted with customary crediting of the source. The American Phytopathological Society, 2009.
Following MAMP- or effector-triggered immunity, plants can respond with a panoply of defense responses to halt pathogen growth. These responses include physical changes (e.g., cell wall thickening, callose deposition, formation of cork layers, or the formation of tyloses in xylem vessels) and biochemical responses (e.g., production of reactive oxygen species [ROS] or signaling compounds such as salicylic acid (SA), jasmonic acid, abscisic acid, and ethylene) that perturb infection (Chisholm et al. 2006; Jones and Dangl 2006). In addition, de novo production of various defense-related proteins and secondary metabolites such as phytoalexins and various phenolics can accumulate both locally and systemically (Hammerschmidt 1999; van Loon et al. 2006). Gene expression profiling studies have shown that substantial changes in host gene expression are associated with the resistance response to a variety of plant pathogen classes (e.g., nematode, viral, bacterial, fungal, or oomycete pathogens). Although plants can specifically activate particular defense responses depending on the nature of the pathogen (Thomma et al. 2001), the optimal defense tactic is to initiate all available defense mechanisms so that at least some may be effective against a particular pathogen (Katagiri 2004). For example, even though transcripts of the pathogenesis-related $(P R)$ genes $P R-1$ and PR13/Thionin are induced after Nicotiana attenuata is challenged with Pseudomonas syringae pv. tomato or Manduca sexta larvae, only PR13/ Thionin had antibacterial activity and neither PR protein provided resistance to herbivores (Rayapuram et al. 2008). Inoculation with Alternaria brassicicola induced SA-dependent defense responses in Arabidopsis, but these responses did not halt pathogen growth and relied on induced jasmonic acid-dependent responses for optimum resistance (Thomma et al. 1998). This "shoot first-ask questions later" strategy, although largely successful in keepings plants free from disease, is energy intensive. Indeed, a common feature in many microarray papers that profile the resistance response to a particular pathogen is a gene list containing primary metabolism genes that likely play a role in providing energy for the resistance response.

The induction of the wide array of defense mechanisms described above involves a massive redistribution of energy toward the defense response. Although there has been continued focus on pathogen recognition and downstream signaling in plant defense, the ability to recruit energy through various energy-producing primary metabolism pathways has received much less attention. Nutrients available for pathogen metabolism during a susceptible interaction may be a consequence of host cell leakage during colonization or pathogen manipulation of the plant to provide nutrients rather than a reflection of an active host defense response; therefore, this review will not focus on pathogen metabolism or host metabolism during the compatible interaction. Readers are directed to recent publica- 
tions that cover these topics (Bolton and Thomma 2008; Divon and Fluhr 2007; Solomon et al. 2003; Walters and Bingham 2007). Instead, this review will focus primarily on changes in host physiology and primary metabolism with regard to their role in the resistance response during the incompatible interaction.

\section{Plant defense is energy intensive.}

After the pathogen (MAMP or effector) is recognized, the term "induced resistance" is used broadly in this review to refer to localized physical and biochemical responses that are initiated to inhibit pathogen growth, including subsequent nonspecific resistance that can spread systemically called systemic acquired resistance (SAR) (Sticher et al. 1997). On the surface, such an inducible resistance strategy has the disadvantage of allowing the pathogen to proliferate until the pathogen is recognized and defense is deployed. On the other hand, constitutively expressed resistance would presumably protect the plant immediately upon initiation of pathogen infection. Why, then, is the latter not a common defense strategy? It is thought that constitutive defense traits have costs that outweigh their benefits, especially in the absence of pathogens when defense traits are not needed. Several earlier studies have shown that allocating resources toward the defense response occurs at the expense of plant fitness (growth and yield), suggesting that defense-related products are autotoxic (Baldwin and Callahan 1993) or that resistance is energetically costly (Fig. 1) (Heil et al. 2000; Smedegaard-Petersen and Stolen 1981; Zangerl et al. 1997). For example, avirulent isolates of powdery mildew caused a reduction in seed weight and protein content when inoculated on barley (Smedegaard-Petersen and Stolen 1981). Wild parsnip plants had reduced biomass after wound treatment that was thought to be the result of the diversion of energy and materials to the defense response (Zangerl et al. 1997). Transformants of $N$. attenuata that were unable to produce defense-related trypsin proteinase inhibitors grew faster and taller, flowered earlier, and produced more seed than wildtype plants (Zavala et al. 2004). Studies in Arabidopsis also indicate that plant defense is energy intensive. For example, approximately 650 genes were differentially expressed within 10 min of inoculation of Arabidopsis with avirulent $P$. syringae pv. tomato, ultimately culminating in more that 2,000 genes at $7 \mathrm{~h}$ postinoculation that reflected an increased demand for energy and biosynthetic capacity to ward off the attack (Scheideler et al. 2002). Arabidopsis mutants with constitutive production of SA or defense gene expression have a decrease in fitness-relevant processes such as growth and reproduction, whereas mutants suppressed in induced resistance signaling under pathogen-free conditions exhibit increased fitness (Fig. 1) (Heil and Baldwin 2002 and references therein). For example, the defense no death (dnd1) mutation in Arabidopsis causes constitutive systemic resistance and elevated levels of SA to give heightened resistance against a variety of virulent bacterial, fungal, and viral pathogens, but plants display a dwarfed morphology (Clough et al. 2000; Genger et al. 2008). Isolation of constitutive PR gene expression (cpr) mutants has shown that they have elevated levels of $P R$ gene expression and enhanced pathogen resistance without SAR induction but are much smaller in size compared with the wild type (Bowling et al. 1997; Clarke et al. 1998). On the other hand, the ethyleneinsensitive 2 (ein2) mutation in Arabidopsis blocks ethylene signaling, increases susceptibility to necrotrophic pathogens, and yields plants that are taller and produce more seed than the wild type (Geraats et al. 2003; Greenberg et al. 2000; Thomma et al. 1999). Interestingly, the mycorrhizal endophytic fungus Sebacina vermifera apparently exploits this phenomenon by impairing ethylene production to promote plant growth (Barazani et al. 2007).

Defense responses can be primed for amplified expression upon pathogen attack. Priming has the benefit of maintaining the defense arsenal dormant until after pathogen infection, thereby alleviating defense costs under pathogen-free conditions. Recently, van Hulten and associates (2006) demonstrated that priming with $\beta$-aminobutyric acid and benzothiadiazole invokes fewer costs than induced resistance by showing that primed plants had levels of disease protection similar to the cprl mutant, with only marginal reductions in growth, whereas induction of direct defenses causes much stronger reductions in plant growth and reduced seed production.

Despite the connection between plant defense and fitnessrelated costs, it should not be assumed that there is always a direct competition for resources and that reductions in growth are due to carbon limitation from a defense response. Indeed, it has been proposed that consumption of carbon for biosynthesis of defense-related processes triggers the plant to adjust growth that can be sustained at a reduced level of carbon availability (Smith and Stitt 2007). Moreover, the costs of inducible resistance are not easily measured (Purrington 2000; Walters and Boyle 2005) and some studies have shown that no costs were associated with disease resistance (Gianoli and Niemeyer 1997; Iriti and Faoro 2003), that fitness costs depend on the environment in which they are measured (Agrawal 2000;

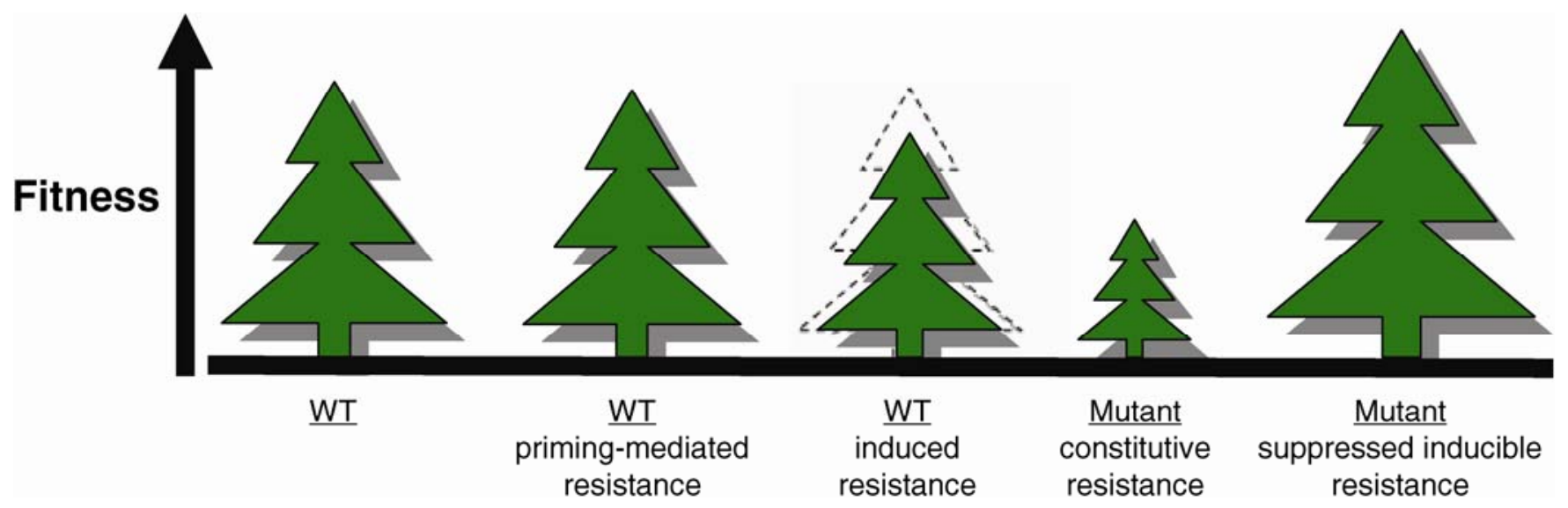

Fig. 1. Hypothetical relationship between resistance and plant fitness. Wild-type (WT) plants undergoing induced resistance potentially utilize resources at the expense of plant fitness. However, induced resistance does not always affect fitness (dashed line). Priming-induced resistance confers fitness traits similar to the WT. Mutants with constitutive resistance phenotypes have less fitness while mutants with suppressed inducible fitness have increased fitness in pathogen-free environments. 
Dietrich et al. 2005) or on the fertility of the soil (Ros et al. 2008; Walls et al. 2005). Therefore, readers are referred to recent and seminal reviews on the allocation costs of plant defense (Brown 2002; Felton and Korth 2000; Heil and Baldwin 2002; Heil and Bostock 2002; Herms and Mattson 1992; Kliebenstein and Rowe 2008; Purrington 2000; SmedegaardPetersen and Tolstrup 1985; Walters and Heil 2007; Walters et al. 2005; Walters and Boyle 2005).

Whether or not plant defense represents an allocation cost to plant fitness, there is little doubt that plant defense is energy intensive. The activation of defense responses places a high metabolic demand upon the infected region-carbon skeletons are required for the synthesis of new molecules and energy is required to fuel biosynthesis. For example, the production of PR proteins, classic markers of the defense response, may constitute up to $10 \%$ of the total soluble protein of an infected leaf (Heil and Bostock 2002) and PR protein-encoding genes are very prevalent in microarray studies of plant defense responses to a wide range of pathogens (Bolton et al. 2008b; van Loon and van Strien 1999; Wan et al. 2002). Rates of host respiration have long been known to increase during resistance responses, further suggesting that demands on cellular metabolism increase to provide energy for the response (SmedegaardPetersen and Tolstrup 1985).

\section{Photosynthesis reduction during plant defense-cause or consequence?}

During photosynthesis, plants harvest light energy to generate ATP and reducing power in the form of NADPH that can be utilized in the production of assimilates for various biological processes. Because plant defense responses may alter the pool size of a range of metabolic intermediates, photosynthetic metabolism is likely to be influenced as it adjusts to meet the demands of the cell. Two hypotheses could be proposed as to the relationship between photosynthesis and energy for the defense response. First, from a supply-and-demand standpoint, it is reasonable to assume that rates of photosynthesis could increase to supply the carbon skeletons, energy, and reducing equivalents required to support the plant defense. On the other hand, if disposable cellular activities are reduced during the resistance response (Somssich and Hahlbrock 1998), the production of defense-related compounds becomes "top priority," with photosynthetic rates reduced until pathogenic growth has been terminated. Indeed, most studies on photosynthesis and plant defense have shown that rates of photosynthesis are reduced locally after treatment with virulent or avirulent pathogens (Berger et al. 2004; Berger et al. 2007a; Bonfig et al. 2006; Chou et al. 2000; Doehlemann et al. 2008; Horst et al. 2008; Manter et al. 2007; Scharte et al. 2005; Swarbrick et al. 2006; Zou et al. 2005), after herbivore attack or wounding (Hermsmeier et al. 2001; Schröder et al. 2005; Schwachtje and Baldwin 2008; Zangerl et al. 2002), or after hormone treatment (Reinbothe et al. 1994). In addition to freeing up resources that can be used for the defense response (Somssich and Hahlbrock 1998), a decrease in the photosynthetic rate may protect the photosynthetic apparatus against oxidative damage (Niyogi 2000) or be a consequence of oxidative damage (Blokhina et al. 2003). Although such decreases are typically localized near the infection area, studies have shown that photosynthesis rates increase in uninfected leaves of plants being attacked by virulent pathogens (Murray and Walters 1992; Roberts and Walters 1986; Williams and Ayres 1981). Interestingly, when the elevated rates of photosynthesis that were observed in uninfected leaves were artificially reduced by shading, the efficacy of SAR to rust infection was also reduced in these leaves (Murray and Walters 1992).

Studies of photosynthetic rate during plant defense have been augmented by chlorophyll fluorescence imaging tech- niques that allow noninvasive monitoring of photosynthesis performance in vivo (Oxborough 2004; Scholes and Rolfe 1996). Scharte and associates (2005) used chlorophyll fluorescence imaging to show that rates of photosynthesis were nearly zero at the periphery of initial infection sites before the final steps of defense and cell death were initiated during the incompatible Phytophthora nicotianae-tobacco interaction. Swarbrick and associates (2006) used chlorophyll fluorescence imaging to show that photosynthesis is reduced both at the center of attempted pathogen penetration sites and in surrounding cells during the resistance response mediated by Mla12 (race specific) and mlo (broad spectrum) in barley to powdery mildew. This decrease is due not only to the elimination of green (photosynthetic) leaf area as a consequence of the hypersensitive response (HR) but also to an alteration in host metabolism (Swarbrick et al. 2006). Indeed, herbivoreattacked plants have also been shown to reduce photosynthetic capacity more than the canopy area removed by the herbivore (Zangerl et al. 2002).

The repression of photosynthesis in the incompatible interaction between Arabidopsis and Pseudomonas syringae did not correlate with downregulation of transcripts for ribulosebisphosphate carboxylase (RbcS) and chlorophyll a/b-binding $(\mathrm{Cab})$ genes involved in dark and light reactions of photosynthesis, respectively, when analyzed from whole leaves (Bonfig et al. 2006). Localized $R b c S$ and $C a b$ repression may not be detectable in whole leaves due to mass RNA dilution from the majority of cells not involved in the defense response; therefore, Bonfig and associates (2006) speculate that plants avoid systemic downregulation to keep assimilate production high, especially because most cells in an incompatible interaction will not encounter the pathogen. To minimize the effects of RNA dilution, microextraction of mRNA from resistant or infected barley epidermal cells $18 \mathrm{~h}$ after inoculation with powdery mildew was carried out and the results showed that $R b c S$ was downregulated in the compatible interaction while $C a b$ transcripts were downregulated in the incompatible interaction (Gjetting et al. 2007). In another study of the same pathosystem, $R b c S$ and $C a b$ transcripts were both reduced more than 20 -fold in the incompatible interaction (Swarbrick et al. 2006). Although $R b c S$ and $C a b$ transcripts disappear within $12 \mathrm{~h}$ postinoculation of avirulent Phytophthora nicotianae on tobacco, chlorophyll content remained stable, suggesting that light-harvesting photosynthetic antennae remain intact despite low photosynthetic rates (Scharte et al. 2005). Taken together, plants appear to switch off photosynthesis locally in the early stages of the defense reaction.

In some compatible interactions, the zone surrounding an infection site has a stimulated rate of photosynthesis (Berger et al. 2004; Chou et al. 2000). For example, during the compatible interaction between tomato and the pathogens Pseudomonas syringae and Botrytis cinerea, Berger and associates (2004) found the expected zone of inhibited photosynthesis in the direct vicinity of the infection sites but also a distinct stimulation of photosynthesis surrounding the infection sites. It is not clear if the enhanced photosynthesis is due to the plant's attempt to fuel defense responses to limit pathogen growth or fungal manipulation of the plant to co-opt resources for fungal nutrition.

\section{Chloroplasts_-lighting up plant defense.}

Despite the apparent localized repression of photosynthetic metabolism during plant defense, there is evidence that light itself is necessary for development of resistance responses in a number of pathosystems (Roberts and Paul 2006 and references therein). Allen and associates (1999) were the first to measure photosynthesis during the $\mathrm{HR}$ and found that light 
stimulates the oxidative burst. Since then, light has been shown to influence hormone-mediated signal transduction pathways or be necessary for the HR in response to several pathogens (Chandra-Shekara et al. 2006; Genoud et al. 2002; Liu et al. 2007; Mühlenbock et al. 2008; Zeier et al. 2004). However, there are several examples where components of the defense response are both light dependent and light independent in the same pathosystem. For example, light is not necessary to initiate harpin-induced HR in N. sylvestris but the HR is slower to develop in the dark (Garmier et al. 2007). Light is necessary for necrotic symptoms in tomato leaf tissue in the response to elicitors from Cladosporium fulvum but lipoxygenase and lipid peroxidation, important components of the HR, are light independent (Buonaurio and Servili 1999; Peever and Higgins 1989). Other studies have shown that the HR can be initiated in the dark but requires subsequent light for photoproduced ROS (discussed below) for maximum lesion propagation (Liu et al. 2007; Mateo et al. 2004). The HR elicited by cryptogein in $N$. tabacum was mediated by $\mathrm{H}_{2} \mathrm{O}_{2}$ in the light but cell death in the dark was $\mathrm{H}_{2} \mathrm{O}_{2}$ independent and coordinated with lipoxygenase activity, suggesting that fatty acid hydroperoxides play a more prominent role than $\mathrm{H}_{2} \mathrm{O}_{2}$ during the HR in the dark (Montillet et al. 2005). Taken together, the defense response appears to be somewhat plastic, where various resistance components are differentially activated depending on light intensity.

A relatively new role for photosynthetic metabolism is the generation of chloroplast-derived ROS for plant defense. The amount of absorbed light energy in excess of that required by the plant for photosynthetic metabolism is called excess excitation energy (EEE). Therefore, plant leaves must acclimate to ambient light intensities to optimize the use of absorbed light for photosynthesis while, at the same time, minimizing the formation of ROS, which are formed as a result of dissipating EEE (Karpinski et al. 2003). Although EEE is typically associated with a rise in light intensity, any environmental stress that limits photosynthesis metabolism (e.g., stress that affects gas exchange or primary metabolism) can also create EEE under otherwise normal light conditions (Bechtold et al. 2005). It is well known that ROS are generated during the oxidative burst from enhanced enzymatic activity of plasma membrane-bound NADPH oxidases, cell-wall-bound peroxidases, and apoplastic amine oxidases (Apel and Hirt 2004; Lamb and Dixon 1997). Recent evidence has suggested that ROS generation for plant defense could be supplemented from light-driven generation of ROS (Roberts and Paul 2006). In addition, because NADPH oxidase is metabolically costly (due to NADPH consumption), resistance may be facilitated in illuminated tissue because ROS can be supplied at less cost through light-driven reactions compared with ROS generated in the dark (Roberts and Paul 2006).

As noted above, the HR can be initiated under dark conditions (Montillet et al. 2005) but light-generated ROS are required for full lesion development in several pathosystems (Mateo et al. 2004; Montillet et al. 2005; Rustérucci et al. 2001). Liu and associates (2007) observed a rapid shutdown of $\mathrm{CO}_{2}$ fixation in chloroplasts during the HR-like cell death in tobacco, a process that actively creates EEE that generates ROS in chloroplasts. However, suspension-cultured cells lacking mature chloroplasts also undergo HR-like cell death, suggesting that chloroplastderived ROS are not the only ROS that facilitate cell death (Liu et al. 2007). The lesion stimulating disease 1 ( $l s d l)$ mutant of Arabidopsis does not limit the boundaries of cell death after HR elicitation or under long photo periods. It has been shown that $l s d l$ plants have reduced stomatal conductance and are compromised in dissipation of EEE, suggesting that photorespiration and restriction of HR cell death are functionally linked (Mateo et al. 2004). Recently, LSD1 has been shown to suppress an ethylene- and ROS-dependent cell-death pathway that requires the function of immune regulators enhanced disease susceptibility 1 (EDS1) and phytoalexin deficient 4 (PAD4) and is modulated by the redox status in the plastoquinone pool, further supporting the role of chloroplasts in modulating defense responses (Mühlenbock et al. 2008). It should be noted that stomatal closure, a common response to stress that causes a drop in gas exchange, can create conditions that promote EEE and enhanced photorespiration (Fryer et al. 2003; Mateo et al. 2004). Stomatal closure during the HR has previously been described (Melotto et al. 2006; Scharte et al. 2005) and may be a factor in creating EEE that manifest as ROS involved in lipid peroxidation and electrolyte leakage during plant defense (Bechtold et al. 2005). In support of this theory, environmental factors such as high humidity that stall stomatal closure have been shown to slow the HR and inhibit resistance (Jambunathan et al. 2001; Yoshioka et al. 2001).

Other evidence for chloroplast involvement in plant defense has been provided by variegated mutants. Electrolyte leakage has been shown to be reduced in white sectors (areas with defective plastids that lack colored pigment) of variegated Arabidopsis mutants, suggesting that functional chloroplasts are involved in the pathway leading to HR (Genoud et al. 2002). White leaves of the barley mutant Albostrians are more susceptible to Bipolaris sorokiniana (Schäfer et al. 2004) but have higher $\mathrm{H}_{2} \mathrm{O}_{2}$ accumulation and lower SA production compared with green leaves in response to powdery mildew infection (Jain et al. 2004).

\section{Carbohydrate metabolism.}

The localized reduction in photosynthetic metabolism in conjunction with increased cellular demands during the resistance response initiates the transition from source status to sink status in infected tissue. This transition is often accompanied by an increase in cell wall (apoplastic or extracellular) invertase gene expression and activity (Roitsch et al. 2003). After inoculation, apoplastic sucrose concentration is known to increase for several hours during the incompatible interaction (Scharte et al. 2005). The increase in cell-wall invertase activity functions to cleave apoplastic sucrose into glucose and fructose. These hexoses are then transported into the cell by hexose transporters where they are believed to fulfill the energy and carbon requirements for the resistance response (Fig. 2) (Truernit et al. 1996). This transport also reduces hexose concentration in the apoplast, thereby reducing potential nutrients for apoplast-colonizing pathogens (Fotopoulos et al. 2003). In addition, the carbohydrate increase is believed to be a metabolic signal that induces the expression of defense-related genes and repression of photosynthesis (Berger et al. 2004; Chou et al. 2000; Ehness et al. 1997; Herbers et al. 1996, 2000; Kocal et al. 2008; Roitsch et al. 2003; Scholes et al. 1994; Sinha et al. 2002). For example, the accumulation of hexose sugars has been implicated in the repression of photosynthetic genes (Berger et al. 2004; Chou et al. 2000; Kocal et al. 2008; Sinha et al. 2002) and hexokinases can sense soluble hexoses and regulate programmed cell death in plants (Kim et al. 2006), suggesting that sugar sensing mediates a direct link between carbohydrate metabolism and the defense response.

Cell-wall invertase activity also increases after infection in susceptible interactions (Fotopoulos et al. 2003; Greenshields et al. 2004; Hammes et al. 2005; Sutton et al. 2007; Wright et al. 1995) but occurs more rapidly and to a larger degree in the incompatible interaction, with the resulting hexoses localized to portions of the leaf actively involved in the resistance response (Scharte et al. 2005; Swarbrick et al. 2006). Thus, the discrete localization of accumulated hexoses in the infection site supports the importance of spatial context when quantify- 
ing hexose accumulation after infection, perhaps explaining why there is sometimes no correlation between hexose accumulation and pathogen infection in studies that analyzed sugar levels from both infected and uninfected portions of the leaf (Berger et al. 2007b). Interestingly, callose deposition at cellto-cell interfaces blocks sucrose export routes in tobacco leaves in response to avirulent Phytophthora nicotianae. Together with increased cell-wall invertase activity, this may serve to reallocate and retain carbohydrates in cells actively involved in the resistance response (Scharte et al. 2005).

Pathogens also possess extracellular sucrolytic enzymes and preferentially utilize hexose rather than sucrose (Voegele et al. 2001). Therefore, it is not always clear in susceptible interactions whether invertase activity is of fungal origin or an aspect of plant defense against the invading pathogen. Recently, Jobic and associates (2007) used antibodies directed toward sunflower or Sclerotinia sclerotiorum invertases to show that cell-wall invertase activity during the compatible interaction was largely of fungal origin. Interestingly, cell-wall invertase-repressed tomato plants hosted bacterial growth similar to the wild type during the compatible interaction with Xanthomonas campestris pv. vesicatoria (Kocal et al. 2008), suggesting that this bacterium can utilize nutrients besides hexoses during growth in planta. Indeed, pathogen effectors may actively suppress host cell-wall invertase activity during compatible interactions to prevent hexose-mediated defense signaling (Biemelt and Sonnewald 2006). However, a role for cell-wall invertase as a component of plant defense has been shown recently by using RNA interference to repress cell-wall-specific invertase gene expression in tobacco (Essmann et al. 2008). Cell-wall invertase-repressed plants had normal development but defenserelated callose deposition, PR protein activity, and the HR were delayed after infection with avirulent $P$. nicotianae, supporting the notion that cell-wall invertase is a component of plant defense (Essmann et al. 2008).

\section{Nitrogen and amino acid metabolism.}

The assimilation of nitrogen onto carbon skeletons has significant effects on plant development and yield (Lam et al. 1996). Inorganic nitrogen is assimilated into the amino acids glutamine, glutamate, asparagine, and aspartate, which serve as vital nitrogen-transport and storage molecules in crops (Lam et al. 1996). In response to infection, the strong demand to obtain carbon will likely shuttle amino acids into energygenerating pathways such as the tricarboxylic acid (TCA) cycle (discussed below). For example, the enzyme glutamate de-

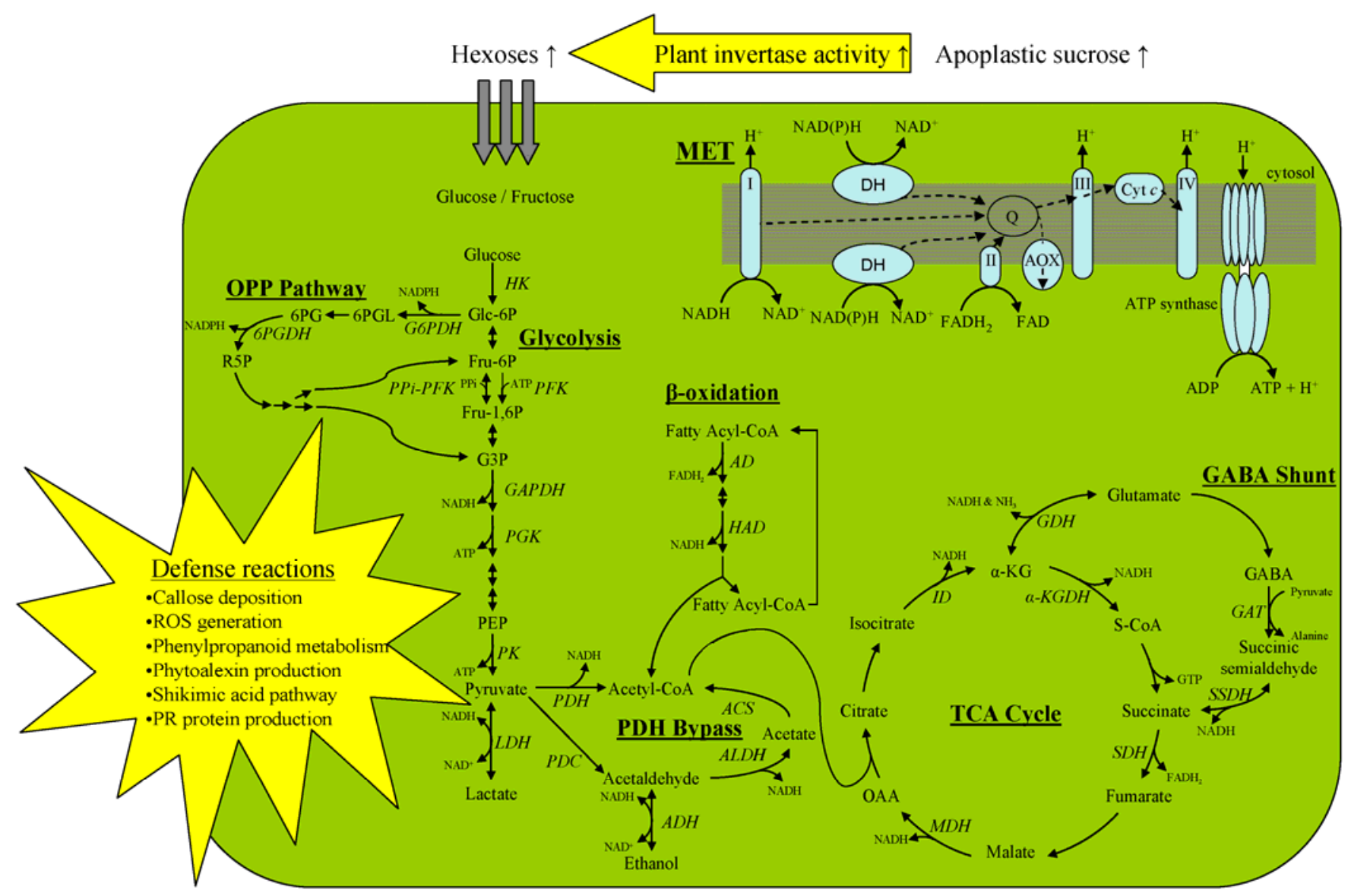

Fig. 2. Primary metabolism pathways involved in plant defense. The pathways of glycolysis, oxidative pentose phosphate (OPP), pyruvate metabolism including the pyruvate dehydrogenase (PDH) bypass, $\beta$-oxidation, TCA cycle, 4 -aminobutyrate $(\gamma$-aminobutyrate) (GABA) shunt, and the mitochondrial electron transport (MET) are shown. Only enzymes that catalyze reactions that are related to energy production are shown. Electron donors $(\mathrm{NAD}(\mathrm{P}) \mathrm{H}$ and $\mathrm{FADH}_{2}$ ) from primary metabolism pathways can be used in the MET to produce ATP or be involved directly in various defense reaction pathways such as in reactive oxygen species (ROS) production. Abbreviations: HK, hexokinase; Glc-6P, glucose 6-phosphate; Fru-6P, fructose-6-phosphate; PPi-PFK pyrophosphate:fructose-6-phosphate 1-phosphotransferase; PFK, phosphofructokinase; Fru-1,6P, fructose-1,6-bisphosphate; G3P, glyceraldehyde-3phosphate; GAPDH, glyceraldehyde-3-phosphate dehydrogenase; PGK, phosphoglycerate kinase; PEP, phosphoenolpyruvate; PK, pyruvate kinase; LDH, lactate dehydrogenase; PDH, pyruvate dehydrogenase; PDC, pyruvate decarboxylase; ALDH, acetaldehyde dehydrogenase; ACS, acetyl-CoA synthase; AD, acyl-CoA dehydrogenase; HAD, 3-L-hydroxyacyl-CoA dehydrogenase; ID, isocitrate dehydrogenase; $\alpha$-KG, $\alpha$-ketoglutarate; $\alpha$-KGDH, $\alpha$-ketoglutarate dehydrogenase; S-CoA, succinyl-CoA; OAA, oxaloacetate; GDH, glutamate dehydrogenase; GAT, 4-aminobutyrate aminotransferase; SSDH, succinic semialdehyde dehydrogenase; DH, internal/external NADH dehydrogenase; Q, ubiquinone; AOX, alternative oxidase; and Cyt $c$, cytochrome c. Adapted from Bolton et al. 2008 . 
hydrogenase (GDH) can release amino nitrogen from amino acids to give a keto-acid and $\mathrm{NH}_{3}$ that can be recycled separately to be used in the TCA cycle and amide formation, respectively (Fig. 2) (Miflin and Habash 2002). Indeed, the 20 protein amino acids can be metabolized into one of seven intermediates ( $\alpha$-ketoglutarate, acetoacetate, acetyl-CoA, fumarate, oxaloacetate, pyruvate, and succinyl-CoA) critical for energy generation in plants.

In addition to shuttling amino acids into energy-generating pathways, nitrogen metabolism has other implications with plant defense. It has been proposed that plants may actively mobilize some nitrogen sources away from infection sites to deprive pathogens of nutrients (Tavernier et al. 2007). For example, in response to infection from the root herbivore Agapeta zoegana, Centaurea maculosa plants reduce wholeplant nitrogen uptake but also reallocate nitrogen from roots to aboveground tissues (Newingham et al. 2007). Several genes normally involved with nitrogen mobilization processes during senescence have also been shown to be upregulated by infection (Pageau et al. 2006; Stephenson et al. 1997; Tavernier et al. 2007). For example, transcripts for glutamine synthetase 1 (GS1), a marker for senescence, was induced within $2 \mathrm{~h}$ of inoculation (Pageau et al. 2006).

Nitrogen can also be directly involved with the defense response through the action of reactive nitrogen species. Reactive nitrogen species, such as nitric oxide (NO), have been shown to be an important aspect of many physiological plant processes, including defense responses (Lamotte et al. 2004). NO is produced in plants using either a nitrate or nitrite-dependent pathway and an L-Arg-dependent pathway (Besson-Bard et al. 2008) and can be directly toxic to invading microbes, affect the redox status of the cell, and, together with ROS, trigger the HR and other defense-related processes (Romero-Puertas et al. 2004; Zaninotto et al. 2006).

Studies have shown that nitrogen deficiency encourages disease development, presumably because nutritionally stressed plants are weaker and, therefore, less able to defend against pathogens, while overfertilization can also promote disease development by providing excess nutrients to support pathogenic growth (Solomon et al. 2003). Based on reports that some pathogen effector genes were induced both in vitro under nitrogen-limiting conditions and during growth in planta, it has been proposed that nitrogen availability for pathogen growth is limiting during infection (Bolton and Thomma 2008; Divon and Fluhr 2007; Walters and Bingham 2007). However, Solomon and Oliver (2001) showed that the total concentration of nitrogen increases to millimolar concentrations in the tomato apoplast during infection with the biotrophic fungus Cladosporium fulvum. Indeed, expression analysis of pathogen effector genes in several pathosystems has shown that they cannot be induced in vitro under nitrogen-limiting conditions even though they are highly expressed in planta (Basse et al. 2000; Fudal et al. 2007; Guo et al. 1996; Khan and Straney 1999; Thomma et al. 2006), suggesting that most nitrogen sources are not limiting during pathogen colonization and effector gene expression is not primarily controlled by nitrogen (Bolton and Thomma 2008).

\section{Respiration.}

Plant respiration is well known to be stimulated during the resistance response (Smedegaard-Petersen and Stolen 1981). Respiration can be divided into three main pathways: glycolysis, the mitochondrial TCA cycle, and mitochondrial electron transport (Fernie et al. 2004). These interconnected pathways function to generate energy equivalents and carbon skeletons that may be used in the biosynthesis of various metabolites.

Glycolysis is a cytosolic pathway that converts glucose to pyruvate, resulting in a small net gain of ATP (Fig. 2). In aerobic conditions, phosphofructokinase (PFK) is the main regulator of glycolysis, catalyzing the irreversible conversion of fructose 6-phosphate to fructose 1,6-bisphosphate, utilizing $1 \mathrm{~mol}$ of ATP in the process. Likewise, pyrophosphate:fructose-6-phosphate 1-phosphotransferase (PPi-dependent PFK [PPi-PFK]) catalyzes the same process but in an ATP-independent manner (Mertens et al. 1990). Transcripts for PPi-PFK are known to accumulate under anoxic conditions (Lasanthi-Kudahettige et al. 2007), perhaps suggesting that this enzyme is used to conserve ATP under suboptimal conditions. Recently, transcripts for PFK and PPi-PFK were both found to be upregulated during the Lr34-mediated response to Puccinia triticina in wheat, indicating that flux through glycolysis is an important aspect of the resistance response (Bolton et al. 2008b).

The oxidative metabolism of pyruvate by pyruvate dehydrogenase $(\mathrm{PDH})$ forms acetyl-CoA that enters the TCA cycle (Fig. 2). PDH is thought to be a key regulatory point for pyruvate flux into the TCA cycle (Fernie et al. 2004). The TCA cycle is a central metabolic pathway for aerobic processes and is responsible for a major portion of carbohydrate, fatty acid, and amino acid oxidation that produces energy and reducing power (Fernie et al. 2004). In the TCA cycle, each acetyl-CoA produces one GTP, one $\mathrm{FADH}_{2}$ and three NADH. FADH 2 and $\mathrm{NADH}$ are reoxidized through oxidative phosphorylation to form ATP, ultimately yielding 15 ATP equivalents per pyruvate molecule entered through the TCA cycle. The upregulation of citrate synthase or $\alpha$-ketoglutarate dehydrogenase during a resistance response, both considered to be rate-limiting enzymes (Strumilo 2005; Wiegand and Remington 1986), suggests an elevated flux through the TCA cycle.

Another pathway involved with the TCA cycle is the 4-aminobutyrate ( $\gamma$-aminobutyrate) (GABA) shunt (Fig. 2), a pathway that produces succinate using either glutamate or $\alpha$-ketoglutarate as substrates (Shelp et al. 1999). GABA is known to be an extracellular signal molecule (Shelp et al. 2006) and the GABA shunt may be involved in supporting the resistance response to pathogens (Bolton et al. 2008b). For example, under particularly energetically demanding conditions, pyruvate from glycolysis can be produced faster than PDH can convert it to acetyl CoA. By providing a second entry point for pyruvate, the GABA shunt provides a means to utilize excess pyruvate for energy production. In addition, the TCA enzymes aconitase, succinyl-CoA ligase, and $\alpha$-ketoglutarate dehydrogenase are inactivated under oxidative stress conditions (Sweetlove et al. 2002; Tretter and Adam-Vizi 2000). During the oxidative stress that occurs during the HR, the GABA shunt may provide a means of keeping NADH generation unaltered through the TCA cycle by bypassing these oxidative stress-sensitive enzymes.

The TCA cycle generates reducing equivalents that are used by the electron transport chain to fuel ATP synthesis (Fig. 2). During electron transport along the cytochrome pathway, the transfer of electrons from NADH and $\mathrm{FADH}_{2}$ to $\mathrm{O}_{2}$ via four inner-membrane protein complexes is coupled to ATP synthesis. Under conditions of high TCA cycle flux, the alternative oxidase (AOX) pathway is often activated to divert electrons from the ubiquinone (Q) pool to form $\mathrm{H}_{2} \mathrm{O}$, allowing excess energy to be lost as heat. Although this pathway does not contribute to ATP production, it can minimize production of mitochondriaderived ROS during programmed cell death (Yip and Vanlerberghe 2001).

The oxidative pentose phosphate (OPP) pathway is involved with the generation of NADPH by the oxidation of glucose-6phosphate, an intermediate also shared with glycolysis (Fig. 2). Glucose-6-phosphate dehydrogenase, the rate-limiting step in the OPP pathway, generates NADPH and is also implicated 
in the proper localization of NPR1, a critical component of the SA defense pathway (Dong 2004). As mentioned above, NADPH-oxidase enzymes are major contributors of ROS during the HR and, consequently, large amounts of NADPH are required. Oxidation of cytosolic hexose phosphates by the OPP pathway is a likely source of NADPH to satisfy NADPH-oxidase activity (Pugin et al. 1997). The OPP pathway also generates fructose-6-phosphate and glyceraldehyde 3-phosphate. During the response to the elicitor cryptogein in tobacco cells, glyceraldehyde-3-phosphate is converted to fructose-1,6bisphosphate and, subsequently, to fructose-6-phosphate by aldolase and PPi-PFK, respectively, suggesting that the pathway toward glucose-6-phosphate is favored, presumably to recycle OPP pathway substrates for NADPH generation (Pugin et al. 1997). Increased levels of stromal OPP pathway metabolites were demonstrated to be at the infection site during the incompatible interaction between Phytophthora nicotianae and tobacco (Scharte et al. 2005).

In addition to these central metabolic pathways, other energygenerating pathways are also upregulated during the defense response. For example, malate metabolism by NADP-malic enzyme is upregulated in response to pathogens and has been speculated to be involved in energy for plant defense through the generation of pyruvate and NADPH (Casati et al. 1999; Schaaf et al. 1995; Widjaja et al. 2009; Zulak et al. 2009). The glyoxylate cycle mediates the conversion of acetyl-CoA to succinate and has been shown be an aspect of the defense response to Pseudomonas syringae pv. tomato in Arabidopsis (Scheideler et al. 2002). The resulting succinate can be transported from the glyoxysome to the mitochondrion, where it can be employed in the TCA cycle. The degradation of fatty acids during $\beta$-oxidation is another potential energy source during plant defense (Fig. 2). The complete oxidation of a fatty acid molecule generates a significant amount of ATP equivalents by producing one $\mathrm{NADH}$, one $\mathrm{FADH}_{2}$, and one acetylCoA for each round of the cycle (Lynen 1955), and the pathway has been shown to be upregulated during the resistance response to several pathogens (Bolton et al. 2008b; Schenk et al. 2003).

\section{Aerobic fermentation.}

The end product of glycolysis, pyruvate, has many fates depending on oxygen supply and the energy requirements of the cell. As mentioned above, the oxidative metabolism of pyruvate by PDH forms acetyl-CoA that enters the TCA cycle during aerobic respiration. In hypoxic conditions, however, pyruvate can also be broken down by lactate dehydrogenase (LDH) to form lactate and $\mathrm{NAD}^{+}$. This serves an important purpose for energy production; namely, the anaerobic regeneration of $\mathrm{NAD}^{+}$for glycolysis. However, as lactate concentration increases cytoplasmic $\mathrm{pH}$ drops, leading to LDH inhibition and activation of pyruvate decarboxylase (PDC) (Davies et al. 1974). PDC catalyzes the irreversible conversion of pyruvate into acetaldehyde and $\mathrm{CO}_{2}$ while the subsequent action of alcohol dehydrogenase (ADH) converts acetaldehyde into ethanol and $\mathrm{NAD}^{+}$during the process of ethanolic fermentation. Indeed, ethanolic fermentation has been suggested as an energy-production pathway even in the presence of oxygen under conditions such as pollen development or abiotic stress (Kursteiner et al. 2003). Alternatively, acetaldehyde produced by PDC can be oxidized to acetate and then converted to acetyl-CoA by the enzymes aldehyde dehydrogenase and acetyl-CoA synthetase in the "PDH bypass" pathway (Tadege et al. 1999). The PDH bypass was recently described in pollen tube development as a means to boost energy or carbon production (Gass et al. 2005) and, in healthy aerial plant tissues with ostensibly normal oxygen levels, to potentially convert toxic fermentative intermediates into acetyl-CoA (Lin and Oliver 2008). The PDH bypass, in conjunction with other primary metabolism pathways, was shown to be induced early in the resistance response mediated by the wheat resistance gene Lr34 (Bolton et al. 2008b), a gene that mediates partial resistance to all races of Puccinia triticina (Bolton et al. 2008a). This indicates that Lr34-mediated resistance requires several metabolic pathways to support cellular energy requirements. Interestingly, this response was not maintained later in the infection period and may explain why Lr34 ultimately fails to confine pathogen growth (Bolton et al. 2008b).

\section{Conclusion.}

The ability to monitor the entire transcriptome of a plant species has led to an accumulation of reports listing differentially expressed genes in response to biotic and abiotic stresses. It is becoming increasingly clear that emphasis placed on differentially expressed pathways rather than individual genes provides the best global perspective of the transcriptome (van Baarlen et al. 2007). Several studies have shown that the resistance response relies on multiple metabolic pathways to support cellular energy requirements (Bolton et al. 2008b; Giri et al. 2006; Lei et al. 2005; Scheideler et al. 2002; Schenk et al. 2003). Taken together, large carbon fluxes into secondary metabolism during the defense response cannot occur without influencing reactions in primary metabolism to support the response. However, it should be taken into account that research on plant-microbe interactions often utilizes pathogen quantities that are not relevant to what occurs in nature. The tendency to "overload" the pathogen during inoculations may partly explain why primary metabolism genes are upregulated during such studies. In addition, plants have likely evolved defense responses that are optimized for certain stages of plant development. For example, the inoculation of seedlings with a pathogen that typically invades adult plants in nature may affect primary metabolism much differently than it would at later growth stages. Such observations should be taken into account in studies of the interplay between primary metabolism and plant defense.

If primary metabolism is reconfigured to support the increased demands of the resistance response, an intriguing question is what responses are the major consumers of primary metabolism output. Phenylpropanoid pathway products, often regarded as phytoalexins due to their antimicrobial properties in vitro and their accumulation to antimicrobial concentrations in plant tissue (Dixon et al. 2002), represent a major flow of carbon from primary metabolism into secondary metabolism (Bolton et al. 2008b; Somssich and Hahlbrock 1998). The shikimic acid pathway, often upregulated in response to pathogen infection, is driven by phosphoenolpyruvate (PEP) from glycolysis and erthrose-4-phosphate from the stromal OPP pathway and provides chorismate as an end product and various intermediates involved in plant defense (Weaver and Herrmann 1997). ROS-producing NADPH oxidase is a major source of ROS and is energetically demanding in terms of NADPH consumption (Lamb and Dixon 1997). A schematic representation of several energy-producing pathways involved in the defense response of plant cells is shown in Figure 2. Although not meant to be exhaustive, this diagram merges together the current understanding of how primary metabolism responds to infection by an avirulent pathogen. Research on primary metabolism and plant defense is in its infancy; therefore, it will be interesting to unravel how other primary metabolism pathways influence the defense response as this aspect of plant-microbe interactions gains momentum. 


\section{ACKNOWLEDGMENTS}

B. Thomma (Wageningen University) and K. Fugate and D. Garvin (United States Department of Agriculture-Agricultural Research Service) are acknowledged for their critical reviews of this manuscript.

\section{LITERATURE CITED}

Agrawal, A. A. 2000. Benefits and costs of induced plant defense for Lepidium virginicum (Brassicaceae). Ecology 81:1804-1813.

Allen, L. J., MacGregor, K. B., Koop, R. S., Bruce, D. H., Karner, J., and Bown, A. W. 1999. The relationship between photosynthesis and a mastoparan-induced hypersensitive response in isolated mesophyll cells. Plant Physiol. 119:1233-1242.

Apel, K., and Hirt, H. 2004. Reactive oxygen species: Metabolism, oxidative stress, and signal transduction. Annu. Rev. Plant Biol. 55:373-399.

Ausubel, F. M. 2005. Are innate immune signaling pathways in plants and animals conserved? Nat. Immunol. 6:973-979.

Baldwin, I. T., and Callahan, P. 1993. Autotoxicity and chemical defense: Nicotine accumulation and carbon gain in solanaceous plants. Oecologia 94:534-541.

Barazani, O., von Dahl, C. C., and Baldwin, I. T. 2007. Sebacina vermifera promotes the growth and fitness of Nicotiana attenuata by inhibiting ethylene signaling. Plant Physiol. 144:1223-1232.

Basse, C. W., Stumpferl, S., and Kahmann, R. 2000. Characterization of a Ustilago maydis gene specifically induced during the biotrophic phase: Evidence for negative as well as positive regulation. Mol. Cell. Biol. 20:329-339.

Bechtold, U., Karpinski, S., and Mullineaux, P. M. 2005. The influence of the light environment and photosynthesis on oxidative signalling responses in plant-biotrophic pathogen interactions. Plant Cell Environ. 28:1046-1055.

Bent, A. F., and Mackey, D. 2007. Elicitors, effectors, and $R$ genes: The new paradigm and a lifetime supply of questions. Annu. Rev. Phytopathol. 45:399-436.

Berger, S., Papadopoulos, M., Schreiber, U., Kaiser, W., and Roitsch, T. 2004. Complex regulation of gene expression, photosynthesis and sugar levels by pathogen infection in tomato. Physiol. Plant. 122:419-428.

Berger, S., Benediktyova, Z., Matous, K., Bonfig, K., Mueller, M. J., Nedbal, L., and Roitsch, T. 2007a. Visualization of dynamics of plant-pathogen interaction by novel combination of chlorophyll fluorescence imaging and statistical analysis: Differential effects of virulent and avirulent strains of P. syringae and of oxylipins on A. thaliana. J. Exp. Bot. 58:797-806.

Berger, S., Sinha, A. K., and Roitsch, T. 2007b. Plant physiology meets phytopathology: Plant primary metabolism and plant-pathogen interactions. J. Exp. Bot. 58:4019-4026.

Besson-Bard, A. L., Pugin, A., and Wendehenne, D. 2008. New insights into nitric oxide signaling in plants. Annu. Rev. Plant Biol. 59:21-39.

Biemelt, S., and Sonnewald, U. 2006. Plant-microbe interactions to probe regulation of plant carbon metabolism. J. Plant Physiol. 163:307-318.

Blokhina, O., Virolainen, E., and Fagerstedt, K. V. 2003. Antioxidants, oxidative damage and oxygen deprivation stress: A review. Ann. Bot. 91:179-194.

Bolton, M. D., and Thomma, B. P. H. J. 2008. The complexity of nitrogen metabolism and nitrogen-regulated gene expression in plant pathogenic fungi. Physiol. Mol. Plant Pathol. 72:104-110.

Bolton, M. D., Kolmer, J. A., and Garvin, D. F. 2008a. Wheat leaf rust caused by Puccinia triticina. Mol. Plant Pathol. 9:563-575.

Bolton, M. D., Kolmer, J. A., Xu, W. W., and Garvin, D. F. 2008b. Lr34mediated leaf rust resistance in wheat: Transcript profiling reveals a high energetic demand supported by transient recruitment of multiple metabolic pathways. Mol. Plant-Microbe Interact. 21:1515-1527.

Bolton, M. D., van Esse, H. P., Vossen, J. H., de Jonge, R., Stergiopoulos, I., Stulemeijer, I. J. E., van den Berg, G. C. M., Borrás-Hidalgo, O., Dekker, H. L., de Koster, C. G., de Wit, P. J. G. M., Joosten, M. H. A. J., and Thomma, B. P. H. J. 2008c. The novel Cladosporium fulvum lysin motif effector Ecp6 is a virulence factor with orthologues in other fungal species. Mol. Microbiol. 69:119-136.

Bonfig, K. B., Schreiber, U., Gabler, A., Roitsch, T., and Berger, S. 2006. Infection with virulent and avirulent $P$. syringae strains differentially affects photosynthesis and sink metabolism in Arabidopsis leaves. Planta 225:1-12.

Bowling, S. A., Clarke, J. D., Liu, Y., Klessig, D. F., and Dong, X. 1997. The cpr5 mutant of Arabidopsis expresses both NPR1-dependent and NPRl-independent resistance. Plant Cell 9:1573-1584.

Brown, J. K. 2002. Yield penalties of disease resistance in crops. Curr. Opin. Plant Biol. 5:339-344.

Buonaurio, R., and Servili, M. 1999. Involvement of lipoxygenase, lipoxygenase pathway volatiles, and lipid peroxidation during the hypersensi- tive reaction of pepper leaves to Xanthomonas campestris pv. vesicatoria. Physiol. Mol. Plant Pathol. 54:155-169.

Casati, P., Drincovich, M. F., Edwards, G. E., and Andreo, C. S. 1999. Malate metabolism by NADP-malic enzyme in plant defense. Photosynth. Res. 61:99-105.

Chandra-Shekara, A. C., Gupte, M., Navarre, D., Raina, S., Raina, R., Klessig, D., and Kachroo, P. 2006. Light-dependent hypersensitive response and resistance signaling against Turnip crinkle virus in Arabidopsis. Plant J. 45:320-334.

Chisholm, S. T., Coaker, G., Day, B., and Staskawicz, B. J. 2006. Host-microbe interactions: Shaping the evolution of the plant immune response. Cell 124:803-814.

Chou, H.-M., Bundock, N., Rolfe, S. A., and Scholes, J. D. 2000. Infection of Arabidopsis thaliana leaves with Albugo candida (white blister rust) causes a reprogramming of host metabolism. Mol. Plant Pathol. 1:99113.

Clarke, J. D., Liu, Y., Klessig, D. F., and Dong, X. 1998. Uncoupling $P R$ gene expression from NPR1 and bacterial resistance: Characterization of the dominant Arabidopsis cpr 6-1 mutant. Plant Cell 10:557-570.

Clough, S. J., Fengler, K. A., and Yu, I. 2000. The Arabidopsis dnd1 "defense, no death" gene encodes a mutated cyclic nucleotide-gated ion channel. Proc. Natl. Acad. Sci. U.S.A. 97:9323-9328.

Davies, D. D., Grego, S., and Kenworthy, P. 1974. The control of the production of lactate and ethanol by higher plants. Planta 118:297-310.

de Wit, P. J. 2007. How plants recognize pathogens and defend themselves. Cell. Mol. Life Sci. 64:2726-2732.

Dietrich, R., Ploss, K., and Heil, M. 2005. Growth responses and fitness costs after induction of pathogen resistance depend on environmental conditions. Plant Cell Environ. 28:211-222.

Divon, H. H., and Fluhr, R. 2007. Nutrition acquisition strategies during fungal infection of plants. FEMS (Fed. Eur. Microbiol. Soc.) Microbiol. Lett. 266:65-74.

Dixon, R. A., Achnine, L., Kota, P., Liu, C. J., Reddy, M. S. S., and Wang, L. 2002. The phenylpropanoid pathway and plant defence-a genomics perspective. Mol. Plant Pathol. 3:371-390.

Doehlemann, G., Wahl, R., Horst, R. J., Voll, L. M., Usadel, B., Poree, F., Stitt, M., Pons-Kühnemann, J., Sonnewald, U., Kahmann, R., and Kämper, J. 2008. Reprogramming a maize plant: Transcriptional and metabolic changes induced by the fungal biotroph Ustilago maydis. Plant J. 56:181-195.

Dong, X. 2004. NPR1, all things considered. Curr. Opin. Plant Biol. 7:547-552.

Ehness, R., Ecker, M., Godt, D. E., and Roitsch, T. 1997. Glucose and stress independently regulate source and sink metabolism and defense mechanisms via signal transduction pathways involving protein phosphorylation. Plant Cell 9:1825.

Essmann, J., Schmitz-Thom, I., Schon, H., Sonnewald, S., Weis, E., and Scharte, J. 2008. RNA interference-mediated repression of cell wall invertase impairs defense in source leaves of tobacco. Plant Physiol. 147:1288-1299.

Felton, G. W., and Korth, K. L. 2000. Trade-offs between pathogen and herbivore resistance. Curr. Opin. Plant Biol. 3:309-314.

Fernie, A. R., Carrari, F., and Sweetlove, L. J. 2004. Respiratory metabolism: Glycolysis, the TCA cycle and mitochondrial electron transport. Curr. Opin. Plant Biol. 7:254-261.

Fotopoulos, V., Gilbert, M. J., Pittman, J. K., Marvier, A. C., Buchanan, A. J., Sauer, N., Hall, J. L., and Williams, L. E. 2003. The monosaccharide transporter gene, AtSTP4, and the cell-wall invertase, $A t^{\beta}$ fruct1, are induced in Arabidopsis during infection with the fungal biotroph Erysiphe cichoracearum. Plant Physiol. 132:821-829.

Fryer, M. J., Ball, L., Oxborough, K., Karpinski, S., Mullineaux, P. M., and Baker, N. R. 2003. Control of ascorbate peroxidase 2 expression by hydrogen peroxide and leaf water status during excess light stress reveals a functional organisation of Arabidopsis leaves. Plant J. 33:691705.

Fudal, I., Ross, S., Gout, L., Blaise, F., Kuhn, M. L., Eckert, M. R., Cattolico, L., Bernard-Samain, S., Balesdent, M. H., and Rouxel, T. 2007. Heterochromatin-like regions as ecological niches for avirulence genes in the Leptosphaeria maculans genome: Map-based cloning of AvrLm6. Mol. Plant-Microbe Interact. 20:459-470.

Garmier, M., Priault, P., Vidal, G., Driscoll, S., Djebbar, R., Boccara, M., Mathieu, C., Foyer, C. H., and De Paepe, R. 2007. Light and oxygen are not required for harpin-induced cell death. J. Biol. Chem. 282:3755637566.

Gass, N., Glagotskaia, T., Mellema, S., Stuurman, J., Barone, M., Mandel, T., Roessner-Tunali, U., and Kuhlemeier, C. 2005. Pyruvate decarboxylase provides growing pollen tubes with a competitive advantage in petunia. Plant Cell 17:2355-2368.

Genger, R. K., Jurkowski, G. I., McDowell, J. M., Lu, H., Jung, H. W., Greenberg, J. T., and Bent, A. F. 2008. Signaling pathways that regulate 
the enhanced disease resistance of Arabidopsis "Defense, No Death" mutants. Mol. Plant-Microbe Interact. 21:1285-1296.

Genoud, T., Buchala, A. J., Chua, N.-H., and Métraux, J.-P. 2002. Phytochrome signalling modulates the SA-perceptive pathway in Arabidopsis. Plant J. 31:87-95.

Geraats, B. P. J., Bakker, P. A. H. M., Lawrence, C. B., Achuo, E. A., Hofte, M., and van Loon, L. C. 2003. Ethylene-insensitive tobacco shows differentially altered susceptibility to different pathogens. Phytopathology 93:813-821.

Gianoli, E., and Niemeyer, H. M. 1997. Lack of costs of herbivoryinduced defenses in a wild wheat: Integration of physiological and ecological approaches. Oikos 80:269-275.

Giri, A. P., Wunsche, H., Mitra, S., Zavala, J. A., Muck, A., Svatos, A., and Baldwin, I. T. 2006. Molecular interactions between the specialist herbivore Manduca sexta (Lepidoptera, Sphingidae) and its natural host Nicotiana attenuata. VII. Changes in the plant's proteome. Plant Physiol. 142:1621-1641.

Gjetting, T., Hagedorn, P. H., Schweizer, P., Thordal-Christensen, H., Carver, T. L. W., and Lyngkjr, M. F. 2007. Single-cell transcript profiling of barley attacked by the powdery mildew fungus. Mol. Plant-Microbe Interact. 20:235-246.

Gohre, V., and Robatzek, S. 2008. Breaking the barriers: Microbial effector molecules subvert plant immunity. Annu. Rev. Phytopathol. 46:189-215.

Gómez-Gómez, L., and Boller, T. 2000. FLS2 an LRR receptor-like kinase involved in the perception of the bacterial elicitor flagellin in Arabidopsis. Mol. Cell 5:1003-1011.

Greenberg, J. T., Silverman, F. P., and Liang, H. 2000. Uncoupling salicylic acid-dependent cell death and defense-related responses from disease resistance in the Arabidopsis mutant acd5. Genetics 156:341-350.

Greenshields, D. L., Feng, W., Selvaraj, G., and YangDou, W. 2004. Activity and gene expression of acid invertases in einkorn wheat (Triticum monococcum) infected with powdery mildew. Can. J. Plant Pathol. 26:506-513

Guo, W., González-Candelas, L., and Kolattukudy, P. E. 1996. Identification of a novel pelD gene expressed uniquely in planta by Fusarium solani f. sp. pisi (Nectria haematococca, mating type VI) and characterization of its protein product as an endo-pectate lyase. Arch. Biochem. Biophys. 332:305-312.

Hammerschmidt, R. 1999. Phytoalexins: What have we learned after 60 years? Annu. Rev. Phytopathol. 37:285-306.

Hammes, U. Z., Schachtman, D. P., Berg, R. H., Nielsen, E., Koch, W., McIntyre, L. M., and Taylor, C. G. 2005. Nematode-induced changes of transporter gene expression in Arabidopsis roots. Mol. Plant-Microbe Interact. 18:1247-1257.

He, P., Shan, L., and Sheen, J. 2007. Elicitation and suppression of microbe-associated molecular pattern-triggered immunity in plant-microbe interactions. Cell. Microbiol. 9:1385-1396.

Heil, M., and Baldwin, I. T. 2002. Fitness costs of induced resistance: Emerging experimental support for a slippery concept. Trends Plant Sci. 7:61-67.

Heil, M., and Bostock, R. M. 2002. Induced systemic resistance (ISR) against pathogens in the context of induced plant defences. Ann. Bot. (Lond.) 89:503-512.

Heil, M., Hilpert, A., Kaiser, W., and Linsenmair, K. E. 2000. Reduced growth and seed set following chemical induction of pathogen defence: Does systemic acquired resistance (SAR) incur allocation costs? J. Ecol. 88:645-654.

Herbers, K., Meuwly, P., Frommer, W. B., Metraux, J. P., and Sonnewald, U. 1996. Systemic acquired resistance mediated by the ectopic expression of invertase: Possible hexose sensing in the secretory pathway. Plant Cell 8:793-803.

Herbers, K., Takahata, Y., Melzer, M., Mock, H. P., Hajirezaei, M., and Sonnewald, U. 2000. Regulation of carbohydrate partitioning during the interaction of Potato virus $Y$ with tobacco. Mol. Plant Pathol. 1:51-59.

Herms, D. A., and Mattson, W. J. 1992. The dilemma of plants-to grow or defend. Q. Rev. Biol. 67:283-335.

Hermsmeier, D., Schittko, U., and Baldwin, I. T. 2001. Molecular interactions between the specialist herbivore Manduca sexta (Lepidoptera, Sphingidae) and its natural host Nicotiana attenuata. I. Large-scale changes in the accumulation of growth- and defense-related plant mRNAs. Plant Physiol. 125:683-700.

Horst, R. J., Engelsdorf, T., Sonnewald, U., and Voll, L. M. 2008. Infection of maize leaves with Ustilago maydis prevents establishment of $\mathrm{C} 4$ photosynthesis. J. Plant Physiol. 165:19-28.

Iriti, M., and Faoro, F. 2003. Does benzothiadiazole-induced resistance increase fitness cost in bean? J. Plant Pathol. 85:265-270.

Jain, S. K., Langen, G., Hess, W., Borner, T., Huckelhoven, R., and Kogel, K.-H. 2004. The white barley mutant Albostrians shows enhanced resistance to the biotroph Blumeria graminis f. sp. hordei. Mol. PlantMicrobe Interact. 17:374-382.
Jambunathan, N., Siani, J. M., and McNellis, T. W. 2001. A humidity-sensitive Arabidopsis copine mutant exhibits precocious cell death and increased disease resistance. Plant Cell 13:2225-2240.

Jobic, C., Boisson, A. M., Gout, E., Rascle, C., Fèvre, M., Cotton, P., and Bligny, R. 2007. Metabolic processes and carbon nutrient exchanges between host and pathogen sustain the disease development during sunflower infection by Sclerotinia sclerotiorum. Planta 226:251-265.

Jones, J. D., and Dangl, J. L. 2006. The plant immune system. Nature 444:323-329.

Kaku, H., Nishizawa, Y., Ishii-Minami, N., Akimoto-Tomiyama, C., Dohmae, N., Takio, K., Minami, E., and Shibuya, N. 2006. Plant cells recognize chitin fragments for defense signaling through a plasma membrane receptor. Proc. Natl. Acad. Sci. U.S.A. 103:11086.

Karpinski, S., Gabrys, H., Mateo, A., Karpinska, B., and Mullineaux, P. M. 2003. Light perception in plant disease defence signalling. Curr. Opin. Plant Biol. 6:390-396.

Katagiri, F. 2004. A global view of defense gene expression regulation-a highly interconnected signaling network. Curr. Opin. Plant Biol. 7:506511.

Khan, R., and Straney, D. C. 1999. Regulatory signals influencing expression of the PDA1 gene of Nectria haematococca MPVI in culture and during pathogenesis of pea. Mol. Plant-Microbe Interact. 12:733-742.

Kim, M., Lim, J.-H., Ahn, C. S., Park, K., Kim, G. T., Kim, W. T., and Pai, H.-S. 2006. Mitochondria-associated hexokinases play a role in the control of programmed cell death in Nicotiana benthamiana. Plant Cell 18:2341-2355.

Kliebenstein, D. J., and Rowe, H. C. 2008. Ecological costs of biotrophic versus necrotrophic pathogen resistance, the hypersensitive response and signal transduction. Plant Sci. 174:551-556.

Kocal, N., Sonnewald, U., and Sonnewald, S. 2008. Cell wall-bound invertase limits sucrose export and is involved in symptom development and inhibition of photosynthesis during compatible interaction between tomato and Xanthomonas campestris pv. vesicatoria. Plant Physiol. 148:1523-1536.

Kursteiner, O., Dupuis, I., and Kuhlemeier, C. 2003. The pyruvate decarboxylase 1 gene of Arabidopsis is required during anoxia but not other environmental stresses. Plant Physiol. 132:968-978.

Lam, H. M., Coschigano, K. T., Oliveira, I. C., Melo-Oliveira, R., and Coruzzi, G. M. 1996. The molecular-genetics of nitrogen assimilation into amino acids in higher plants. Annu. Rev. Plant Physiol. Plant Mol. Biol. 47:569-593

Lamb, C., and Dixon, R. A. 1997. The oxidative burst in plant disease resistance. Annu. Rev. Plant Physiol. Plant Mol. Biol. 48:251-275.

Lamotte, O., Gould, K., Lecourieux, D., Sequeira-Legrand, A., LebrunGarcia, A., Durner, J., Pugin, A., and Wendehenne, D. 2004. Analysis of nitric oxide signaling functions in tobacco cells challenged by the elicitor cryptogein. Plant Physiol. 135:516-529.

Lasanthi-Kudahettige, R., Magneschi, L., Loreti, E., Gonzali, S., Licausi, F., Novi, G., Beretta, O., Vitulli, F., Alpi, A., and Perata, P. 2007. Transcript profiling of the anoxic rice coleoptile. Plant Physiol. 144:218231.

Lei, Z., Elmer, A. M., Watson, B. S., Dixon, R. A., Mendes, P. J., and Sumner, L. W. 2005. A two-dimensional electrophoresis proteomic reference map and systematic identification of 1367 proteins from a cell suspension culture of the model legume Medicago truncatula. Mol. Cell. Proteomics 4:1812-1825.

Lin, M., and Oliver, D. J. 2008. The role of acetyl-coenzyme A synthetase in Arabidopsis. Plant Physiol. 147:1822-1829.

Liu, Y., Ren, D., Pike, S., Pallardy, S., Gassmann, W., and Zhang, S. 2007. Chloroplast-generated reactive oxygen species are involved in hypersensitive response-like cell death mediated by a mitogen-activated protein kinase cascade. Plant J. 51:941-954.

Lynen, F. 1955. Lipide metabolism. Annu. Rev. Biochem. 24:653-688.

Manter, D. K., Kelsey, R. G., and Karchesy, J. J. 2007. Photosynthetic declines in Phytophthora ramorum-infected plants develop prior to water stress and in response to exogenous application of elicitins. Phytopathology 97:850-856.

Mateo, A., Mühlenbock, P., Rustérucci, C., Chang, C. C. C., Miszalski, Z., Karpinska, B., Parker, J. E., Mullineaux, P. M., and Karpinski, S. 2004 LESION SIMULATING DISEASE 1 is required for acclimation to conditions that promote excess excitation energy. Plant Physiol. 136:2818-2830.

Melotto, M., Underwood, W., Koczan, J., Nomura, K., and He, S. Y. 2006. Plant stomata function in innate immunity against bacterial invasion. Cell 126:969-980.

Mertens, E., Larondelle, Y., and Hers, H.-G. 1990. Induction of pyrophosphate:fructose 6-phosphate 1-phosphotransferase by anoxia in rice seedlings. Plant Physiol. 93:584-587.

Miflin, B. J., and Habash, D. Z. 2002. The role of glutamine synthetase and glutamate dehydrogenase in nitrogen assimilation and possibilities 
for improvement in the nitrogen utilization of crops. J. Exp. Bot. 53:979-987.

Miya, A., Albert, P., Shinya, T., Desaki, Y., Ichimura, K., Shirasu, K., Narusaka, Y., Kawakami, N., Kaku, H., and Shibuya, N. 2007. CERK1, a LysM receptor kinase, is essential for chitin elicitor signaling in Arabidopsis. Proc. Natl. Acad. Sci. U.S.A. 104:19613-19618.

Montillet, J. L., Chamnongpol, S., Rusterucci, C., Dat, J., van de Cotte, B., Agnel, J. P., Battesti, C., Inzé, D., Van Breusegem, F., and Triantaphylides, C. 2005. Fatty acid hydroperoxides and $\mathrm{H}_{2} \mathrm{O}_{2}$ in the execution of hypersensitive cell death in tobacco leaves. Plant Physiol. 138:1516-1526.

Mühlenbock, P., Szechyńska-Hebda, M., Płaszczyca, M., Baudo, M., Mullineaux, P. M., Parker, J. E., Karpińska, B., and Karpiński, S. 2008 Chloroplast signaling and LESION SIMULATING DISEASE1 regulate crosstalk between light acclimation and immunity in Arabidopsis. Plant Cell 20:2339-2356.

Murray, D. C., and Walters, D. R. 1992. Increased photosynthesis and resistance to rust infection in upper, uninfected leaves of rusted broad bean (Vicia faba L.). New Phytol. 120:235-242.

Newingham, B. A., Callaway, R. M., and BassiriRad, H. 2007. Allocating nitrogen away from a herbivore: A novel compensatory response to root herbivory. Oecologia 153:913-920.

Niyogi, K. K. 2000. Safety valves for photosynthesis. Curr. Opin. Plant Biol. 3:455-460.

O'Connell, R. J., and Panstruga, R. 2006. Tete a tete inside a plant cell: Establishing compatibility between plants and biotrophic fungi and oomycetes. New Phytol. 171:699-718.

Oxborough, K. 2004. Imaging of chlorophyll a fluorescence: Theoretical and practical aspects of an emerging technique for the monitoring of photosynthetic performance. J. Exp. Bot. 55:1195-1205.

Pageau, K., Reisdorf-Cren, M., Morot-Gaudry, J.-F., and MasclauxDaubresse, C. 2006. The two senescence-related markers, GS1 (cytosolic glutamine synthetase) and $G D H$ (glutamate dehydrogenase), involved in nitrogen mobilization, are differentially regulated during pathogen attack and by stress hormones and reactive oxygen species in Nicotiana tabacum L. leaves. J. Exp. Bot. 57:547-557.

Peever, T. L., and Higgins, V. J. 1989. Electrolyte leakage, lipoxygenase, and lipid peroxidation induced in tomato leaf tissue by specific and nonspecific elicitors from Cladosporium fulvum. Plant Physiol. 90:867-875.

Pugin, A., Frachisse, J. M., Tavernier, E., Bligny, R., Gout, E., Douce, R., and Guern, J. 1997. Early events induced by the elicitor cryptogein in tobacco cells: Involvement of a plasma membrane NADPH oxidase and activation of glycolysis and the pentose phosphate pathway. Plant Cell 9:2077-2091

Purrington, C. B. 2000. Costs of resistance. Curr. Opin. Plant Biol. 3:305308.

Rayapuram, C., Wu, J., Haas, C., and Baldwin, I. T. 2008. PR-13/Thionin but not PR-1 mediates bacterial resistance in Nicotiana attenuata in nature, and neither influences herbivore resistance. Mol. Plant-Microbe Interact. 21:988-1000.

Reinbothe, S., Mollenhauer, B., and Reinbothe, C. 1994. JIPs and RIPs: The regulation of plant gene expression by jasmonates in response to environmental cues and pathogens. Plant Cell 6:1197-1209.

Roberts, A. M., and Walters, D. R. 1986. Stimulation of photosynthesis in uninfected leaves of rust-infected leeks. Ann. Bot. 56:893-896.

Roberts, M. R., and Paul, N. D. 2006. Seduced by the dark side: Integrating molecular and ecological perspectives on the influence of light on plant defence against pests and pathogens. New Phytol. 170:677-699.

Roitsch, T., Balibrea, M. E., Hofmann, M., Proels, R., and Sinha, A. K. 2003. Extracellular invertase: Key metabolic enzyme and PR protein. J. Exp. Bot. 54:513-524.

Romero-Puertas, M. C., Perazzolli, M., Zago, E. D., and Delledonne, M. 2004. Nitric oxide signalling functions in plant-pathogen interactions. Cell. Microbiol. 6:795-803.

Ros, B., Mohler, V., Wenzel, G., and Thümmler, F. 2008. Phytophthora infestans-triggered response of growth-and defense-related genes in potato cultivars with different levels of resistance under the influence of nitrogen availability. Physiol. Plant. 133:386-396.

Rustérucci, C., Aviv, D. H., Holt Iii, B. F., Dangl, J. L., and Parker, J. E. 2001. The disease resistance signaling components EDS1 and PAD4 are essential regulators of the cell death pathway controlled by LSD1 in Arabidopsis. Plant Cell 13:2211-2224.

Schaaf, J., Walter, M. H., and Hess, D. 1995. Primary metabolism in plant defense (regulation of a bean malic enzyme gene promoter in transgenic tobacco by developmental and environmental cues). Plant Physiol. 108:949-960.

Schäfer, P., Hückelhoven, R., and Kogel, K.-H. 2004. The white barley mutant Albostrians shows a supersusceptible but symptomless interaction phenotype with the hemibiotrophic fungus Bipolaris sorokiniana. Mol. Plant-Microbe Interact. 17:366-373
Scharte, J., Schön, H., and Weis, E. 2005. Photosynthesis and carbohydrate metabolism in tobacco leaves during an incompatible interaction with Phytophthora nicotianae. Plant Cell Environ. 28:1421-1435.

Scheideler, M., Schlaich, N. L., Fellenberg, K., Beissbarth, T., Hauser, N. C., Vingron, M., Slusarenko, A. J., and Hoheisel, J. D. 2002. Monitoring the switch from housekeeping to pathogen defense metabolism in Arabidopsis thaliana using cDNA arrays. J. Biol. Chem. 277:10555-10561.

Schenk, P. M., Kazan, K., Manners, J. M., Anderson, J. P., Simpson, R. S., Wilson, I. W., Somerville, S. C., and Maclean, D. J. 2003. Systemic gene expression in Arabidopsis during an incompatible interaction with Alternaria brassicicola. Plant Physiol. 132:999-1010.

Scholes, J. D., and Rolfe, S. A. 1996. Photosynthesis in localised regions of oat leaves infected with crown rust (Puccinia coronata): Quantitative imaging of chlorophyll fluorescence. Planta 199:573-582.

Scholes, J. D., Lee, P. J., Horton, P., and Lewis, D. H. 1994. Invertaseunderstanding changes in the photosynthetic and carbohydrate-metabolism of barley leaves infected with powdery mildew. New Phytol. 126:213-222.

Schröder, R., Forstreuter, M., and Hilker, M. 2005. A plant notices insect egg deposition and changes its rate of photosynthesis. Plant Physiol. 138:470-477.

Schwachtje, J., and Baldwin, I. T. 2008. Why does herbivore attack reconfigure primary metabolism? Plant Physiol. 146:845-851.

Shelp, B. J., Bown, A. W., and McLean, M. D. 1999. Metabolism and functions of gamma-aminobutyric acid. Trends Plant Sci. 4:446-452.

Shelp, B. J., Bown, A. W., and Faure, D. 2006. Extracellular $\gamma$-aminobutyrate mediates communication between plants and other organisms. Plant Physiol. 142:1350-1352.

Sinha, A. K., Hofmann, M. G., Romer, U., Kockenberger, W., Elling, L., and Roitsch, T. 2002. Metabolizable and non-metabolizable sugars activate different signal transduction pathways in tomato. Plant Physiol. 128:1480-1489.

Smedegaard-Petersen, V., and Stolen, O. 1981. Effect of energy requiring defense reactions on yield and grain quality in powdery mildew Erysiphe graminis sp. hordei resistant Hordeum vulgare cultivar Sultan. Phytopathology 71:396-399.

Smedegaard-Petersen, V., and Tolstrup, K. 1985. The limiting effect of disease resistance on yield. Annu. Rev. Phytopathol. 23:475-490.

Smith, A. M., and Stitt, M. 2007. Coordination of carbon supply and plant growth. Plant Cell Environ. 30:1126-1149.

Solomon, P. S., and Oliver, R. P. 2001. The nitrogen content of the tomato leaf apoplast increases during infection by Cladosporium fulvum. Planta 213:241-249.

Solomon, P. S., Tan, K. C., and Oliver, R. P. 2003. The nutrient supply of pathogenic fungi; a fertile field for study. Mol. Plant Pathol. 4:203-210.

Somssich, I. E., and Hahlbrock, K. 1998. Pathogen defence in plants-a paradigm of biological complexity. Trends Plant Sci. 3:86-90.

Stephenson, S. A., Green, J. R., Manners, J. M., and Maclean, D. J. 1997. Cloning and characterisation of glutamine synthetase from Colletotrichum gloeosporioides and demonstration of elevated expression during pathogenesis on Stylosanthes guianensis. Curr. Genet. 31:447-454.

Sticher, L., Mauch-Mani, B., and Métraux, J. P. 1997. Systemic acquired resistance. Annu. Rev. Phytopathol. 35:235-270.

Strumilo, S. 2005. Short-term regulation of the $\alpha$-ketoglutarate dehydrogenase complex by energy-linked and some other effectors. Biochem. (Moscow) 70:726-729.

Sutton, P. N., Gilbert, M. J., Williams, L. E., and Hall, J. L. 2007. Powdery mildew infection of wheat leaves changes host solute transport and invertase activity. Physiol. Plant. 129:787-795.

Swarbrick, P. J., Schulze-Lefert, P., and Scholes, J. D. 2006. Metabolic consequences of susceptibility and resistance (race-specific and broadspectrum) in barley leaves challenged with powdery mildew. Plant Cell Environ. 29:1061-1076.

Sweetlove, L. J., Heazlewood, J. L., Herald, V., Holtzapffel, R., Day, D. A., Leaver, C. J., and Millar, A. H. 2002. The impact of oxidative stress on Arabidopsis mitochondria. Plant J. 32:891-904.

Tadege, M., Dupuis, I., and Kuhlemeier, C. 1999. Ethanolic fermentation: New functions for an old pathway. Trends Plant Sci. 4:320-325.

Tavernier, V., Cadiou, S., Pageau, K., Lauge, R., Reisdorf-Cren, M., Langin, T., and Masclaux-Daubresse, C. 2007. The plant nitrogen mobilization promoted by Colletotrichum lindemuthianum in Phaseolus leaves depends on fungus pathogenicity. J. Exp. Bot. 58:3351-3360.

Thomma, B. P., Eggermont, K., Tierens, K. F., and Broekaert, W. F. 1999. Requirement of functional ethylene-insensitive 2 gene for efficient resistance of Arabidopsis to infection by Botrytis cinerea. Plant Physiol. 121:1093-1102

Thomma, B. P. H. J., Eggermont, K., Penninckx, I. A. M. A., Mauch-Mani, B., Vogelsang, R., Cammue, B. P. A., and Broekaert, W. F. 1998. Separate jasmonate-dependent and salicylate-dependent defense-response pathways in Arabidopsis are essential for resistance to distinct micro- 
bial pathogens. Proc. Natl. Acad. Sci. U.S.A. 95:15107-15111.

Thomma, B. P. H. J., Tierens, K. F. M., Penninckx, I. A. M. A., MauchMani, B., Broekaert, W. F., and Cammue, B. P. A. 2001. Different micro-organisms differentially induce Arabidopsis disease response pathways. Plant Physiol. Biochem. 39:673-680.

Thomma, B. P. H. J., Bolton, M. D., Clergeot, P. H., and de Wit, P. J. G. M. 2006. Nitrogen controls in planta expression of Cladosporium fulvum Avr9 but no other effector genes. Mol. Plant Pathol. 7:125-130.

Tretter, L., and Adam-Vizi, V. 2000. Inhibition of Krebs cycle enzymes by hydrogen peroxide: A key role of $\alpha$-ketoglutarate dehydrogenase in limiting NADH production under oxidative stress. J. Neurosci. 20:89728979.

Truernit, E., Schmid, J., Epple, P., Illig, J., and Sauer, N. 1996. The sinkspecific and stress-regulated Arabidopsis STP4 gene: Enhanced expression of a gene encoding a monosaccharide transporter by wounding, elicitors, and pathogen challenge. Plant Cell 8:2169-2182.

van Baarlen, P., van Esse, H. P., Siezen, R. J., and Thomma, B. P. H. J. 2007. Challenges in plant cellular pathway reconstruction based on gene expression profiling. Trends Plant Sci. 13:44-50.

van Esse, H. P., van't Klooster, J. W., Bolton, M. D., Yadeta, K. A., van Baarlen, P., Boeren, S., Vervoort, J., de Wit, P. J. G. M., and Thomma, B. P. H. J. 2008. The Cladosporium fulvum virulence protein Avr2 inhibits host proteases required for basal defense. Plant Cell 20:1948-1963.

van Hulten, M., Pelser, M., van Loon, L. C., Pieterse, C. M. J., and Ton, J. 2006. Costs and benefits of priming for defense in Arabidopsis. Proc. Natl. Acad. Sci. U.S.A. 103:5602-5607.

van Loon, L. C., and van Strien, E. A. 1999. The families of pathogenesisrelated proteins, their activities, and comparative analysis of PR-1 type proteins. Physiol. Mol. Plant Pathol. 55:85-97.

van Loon, L. C., Rep, M., and Pieterse, C. M. 2006. Significance of inducible defense-related proteins in infected plants. Annu. Rev. Phytopathol. 44:135-162.

Voegele, R. T., Struck, C., Hahn, M., and Mendgen, K. 2001. The role of haustoria in sugar supply during infection of broad bean by the rust fungus Uromyces fabae. Proc. Natl. Acad. Sci. U.S.A. 98:8133-8138.

Walls, R., Appel, H., Cipollini, M., and Schultz, J. 2005. Fertility, root reserves and the cost of inducible defenses in the perennial plant Solanum carolinense. J. Chem. Ecol. 31:2263-2288.

Walters, D., and Heil, M. 2007. Costs and trade-offs associated with induced resistance. Physiol. Mol. Plant Pathol. 71:3-17.

Walters, D., Walsh, D., Newton, A., and Lyon, G. 2005. Induced resistance for plant disease control: Maximizing the efficacy of resistance elicitors. Phytopathology 95:1368-1373.

Walters, D. R., and Bingham, I. J. 2007. Influence of nutrition on disease development caused by fungal pathogens: Implications for plant disease control. Ann. Appl. Biol. 151:307-324.

Walters, D. R., and Boyle, C. 2005. Induced resistance and allocation costs: What is the impact of pathogen challenge? Physiol. Mol. Plant Pathol. 66:40-44.

Wan, J., Dunning, M. F., and Bent, A. F. 2002. Probing plant-pathogen interactions and downstream defense signaling using DNA microarrays.
Funct. Integr. Genomics 2:259-273.

Weaver, L. M., and Herrmann, K. M. 1997. Dynamics of the shikimate pathway in plants. Trends Plant Sci. 2:346-351.

Widjaja, I., Naumann, K., Roth, U., Wolf, N., Mackey, D., Dangl, J. L., Scheel, D., and Lee, J. 2009. Combining subproteome enrichment and Rubisco depletion enables identification of low abundance proteins differentially regulated during plant defense. Proteomics 9:138-147.

Wiegand, G., and Remington, S. J. 1986. Citrate synthase: Structure, control, and mechanism. Annu. Rev. Biophys. Biophys. Chem. 15:97117.

Williams, G. M., and Ayres, P. G. 1981. Effects of powdery mildew and water stress on $\mathrm{CO}_{2}$ exchange in uninfected leaves of barley. Plant Physiol. 68:527-530.

Wright, D. P., Baldwin, B. C., Shephard, M. C., and Scholes, J. D. 1995. Source-sink relationships in wheat Leaves infected with powdery mildew. I. Alterations in carbohydrate-metabolism. Physiol. Mol. Plant Pathol. 47:237-253

Yip, J. Y. H., and Vanlerberghe, G. C. 2001. Mitochondrial alternative oxidase acts to dampen the generation of active oxygen species during a period of rapid respiration induced to support a high rate of nutrient uptake. Physiol. Plant. 112:327-333.

Yoshioka, K., Kachroo, P., Tsui, F., Sharma, S. B., Shah, J., and Klessig, D. F. 2001. Environmentally sensitive, SA-dependent defense responses in the cpr22 mutant of Arabidopsis. Plant J. 26:447-459.

Zangerl, A. R., Arntz, A. M., and Berenbaum, M. R. 1997. Physiological price of an induced chemical defense: Photosynthesis, respiration, biosynthesis, and growth. Oecologia 109:433-441.

Zangerl, A. R., Hamilton, J. G., Miller, T. J., Crofts, A. R., Oxborough, K. Berenbaum, M. R., and de Lucia, E. H. 2002. Impact of folivory on photosynthesis is greater than the sum of its holes. Proc. Natl. Acad. Sci. U.S.A. 99:1088-1091.

Zaninotto, F., Camera, S. L., Polverari, A., and Delledonne, M. 2006. Cross talk between reactive nitrogen and oxygen species during the hypersensitive disease resistance response. Plant Physiol. 141:379-383.

Zavala, J. A., Patankar, A. G., Gase, K., and Baldwin, I. T. 2004. Constitutive and inducible trypsin proteinase inhibitor production incurs large fitness costs in Nicotiana attenuata. Proc. Natl. Acad. Sci. U.S.A 101:1607-1612.

Zeier, J., Pink, B., Mueller, M. J., and Berger, S. 2004. Light conditions influence specific defence responses in incompatible plant-pathogen interactions: Uncoupling systemic resistance from salicylic acid and PR-1 accumulation. Planta 219:673-683.

Zou, J., Rodriguez-Zas, S., Aldea, M., Li, M., Zhu, J., Gonzalez, D. O., Vodkin, L. O., DeLucia, E., and Clough, S. J. 2005. Expression profiling soybean response to Pseudomonas syringae reveals new defenserelated genes and rapid HR-specific downregulation of photosynthesis Mol. Plant-Microbe Interact. 18:1161-1174.

Zulak, K. G., Khan, M. F., Alcantara, J., Schriemer, D. C., and Facchini, P. J. 2009. Plant defense responses in opium poppy cell cultures revealed by liquid chromatography-tandem mass spectrometry proteomics. Mol. Cell. Proteomics 8:86-98. 